\title{
Everything you always wanted to know about gene flow in tropical landscapes (but were afraid to ask)
} \author{
Cristian Malta Lanes ${ }^{1}$, Yessica Rico $^{4}$ ， Rodolfo Jaffé Corresp. 1, 5 \\ 1 Instituto Tecnológico Vale, Belém, PA, Brazil \\ 2 Instituto de Ciências Biológicas, Universidade Federal do Pará, Belém, Pará, Brazil \\ 3 Departamento de Botânica, Museu Paraense Emílio Goeldi, Belém, Pará, Brazil \\ 4 Instituto de Ecología, CONACYT, Pátzcuaro, Michoacán, Mexico \\ 5 Departamento de Ecologia, Universidade de São Paulo, São Paulo, São Paulo, Brazil \\ Corresponding Author: Rodolfo Jaffé \\ Email address: r.jaffe@ib.usp.br
}

Waléria Pereira Monteiro ${ }^{1}$, Jamille Costa Veiga ${ }^{2}$, Amanda Reis Silva ${ }^{3}$, Carolina da Silva Carvalho $^{1}$, Éder $^{\text {Ema }}$

The bulk of the world's biodiversity is found in tropical regions, which are increasingly threatened by the human-led degradation of natural habitats. Yet, little is known about tropical biodiversity responses to habitat loss and fragmentation. Here we review all available literature assessing landscape effects on gene flow in tropical species, aiming to help unravel the factors underpinning functional connectivity in the tropics. We map and classify studies by focus species, the molecular markers employed, statistical approaches to assess landscape effects on gene flow, and the evaluated landscape and environmental variables. We then compare qualitatively and quantitatively landscape effects on gene flow across species and units of analysis. We found 69 articles assessing landscape effects on gene flow in tropical organisms, most of which were published in the last five years, were concentrated in the Americas, and focused on amphibians or mammals. Most studies employed population-level approaches, microsatellites were the preferred type of markers, and Mantel and partial Mantel tests the most common statistical approaches used. While elevation, land cover and forest cover were the most common gene flow predictors assessed, habitat suitability was found to be a common predictor of gene flow. A third of all surveyed studies explicitly assessed the effect of habitat degradation, but only 14 of these detected a reduced gene flow with increasing habitat loss. Elevation was responsible for most significant microsatellite-based IBR effects and a single study reported significant isolation by non-forested areas in an ant. Our study reveals important knowledge gaps on the study of landscape effects on gene flow in tropical organisms, and provides useful guidelines on how to fill them. 
1 Everything you always wanted to know about gene flow in tropical

2 landscapes (but were afraid to ask)

3

4 Waléria Pereira Monteiro ${ }^{1}$, Jamille Costa Veiga ${ }^{2}$, Amanda Reis Silva ${ }^{1,3}$, Carolina da Silva

5 Carvalho $^{1}$, Éder Cristian Malta Lanes ${ }^{1}$, Yessica Rico ${ }^{4}$, Rodolfo Jaffé $1,5 *$

6

$7 \quad{ }^{1}$ Instituto Tecnológico Vale, Rua Boaventura da Silva 955, 66055-090 Belém, Pará, Brazil.

$8{ }^{2}$ Instituto de Ciências Biológicas, Universidade Federal do Pará, Belém, Pará, Brazil.

$9 \quad{ }^{3}$ Departamento de Botânica, Museu Paraense Emílio Goeldi, Belém, Pará, Brazil.

$10{ }^{4}$ Instituto de Ecología, CONACYT, Pátzcuaro, Michoacán, Mexico.

$11{ }^{5}$ Departamento de Ecologia, Universidade de São Paulo, São Paulo, São Paulo, Brazil.

$13 *$ Corresponding author

14 Email: rodolfo.jaffe@,itv.org / Phone: +55 (91) 32135523 
17 Abstract

18 The bulk of the world's biodiversity is found in tropical regions, which are increasingly

19 threatened by the human-led degradation of natural habitats. Yet, little is known about tropical

20 biodiversity responses to habitat loss and fragmentation. Here we review all available literature

21 assessing landscape effects on gene flow in tropical species, aiming to help unravel the factors

22 underpinning functional connectivity in the tropics. We map and classify studies by focus species,

23 the molecular markers employed, statistical approaches to assess landscape effects on gene flow,

24 and the evaluated landscape and environmental variables. We then compare qualitatively and

25 quantitatively landscape effects on gene flow across species and units of analysis. We found 69

26 articles assessing landscape effects on gene flow in tropical organisms, most of which were

27 published in the last five years, were concentrated in the Americas, and focused on amphibians or

28 mammals. Most studies employed population-level approaches, microsatellites were the preferred

29 type of markers, and Mantel and partial Mantel tests the most common statistical approaches

30 used. While elevation, land cover and forest cover were the most common gene flow predictors

31 assessed, habitat suitability was found to be a common predictor of gene flow. A third of all

32 surveyed studies explicitly assessed the effect of habitat degradation, but only 14 of these

33 detected a reduced gene flow with increasing habitat loss. Elevation was responsible for most

34 significant microsatellite-based IBR effects and a single study reported significant isolation by

35 non-forested areas in an ant. Our study reveals important knowledge gaps on the study of

36 landscape effects on gene flow in tropical organisms, and provides useful guidelines on how to

37 fill them.

41 Keywords: Functional connectivity; isolation by resistance; landscape genetics; matrix permeability; tropical biodiversity. 


\section{Introduction}

About two-thirds of all known species occur in tropical forests and the majority of the world's most threatened biodiversity hotspots are in the tropics (Myers et al., 2000; Brown, 2014). Extinction rates from habitat loss and fragmentation are acute in the region, and the degradation of essential ecosystem functions and services are threatening billions of people living in tropical countries (Bradshaw, Sodhi \& Brook, 2009). However, the vast majority of studies assessing biodiversity responses to habitat degradation have been undertaken in temperate regions due to a lower investment in research and development in tropical countries (Collen et al., 2008; Barlow et al., 2018). For instance, a recent analysis of 182 studies describing links between biodiversity and ecosystem function (Clarke et al., 2017) found that only 13\% were carried in the tropics, and nearly half of these ( $42 \%)$ were conducted in a single country (Costa Rica). There is thus a pressing need to reduce the knowledge gap concerning the impact of the degradation of natural habitats on tropical biodiversity.

Community-level approaches assessing biodiversity responses to habitat degradation have focused on measuring changes in species richness, composition, and the abundance of indicator species (Morin, 2009). While these metrics underpin ecosystem function, they may not always be the best proxies to detect rapid responses to habitat loss and fragmentation. Local species extinctions may occur after long periods of time since the onset of disturbance (Jackson \& Sax, 2009), whereas species abundance can be affected by multiple environmental or demographic factors unrelated to habitat degradation (Ehrlén \& Morris, 2015). Moreover, complex interspecific interactions can make natural communities resilient to environmental change and thus mask the effect of habitat degradation on community composition (Devictor, Julliard \& Jiguet, 2008). Instead, population-level metrics based on genetic information can offer a higher resolution to detect rapid responses to environmental change (Manel \& Holderegger, 2013a). For instance, changes in genetic diversity and gene flow patterns in response to recent landscape modification have been found across several species (Balkenhol et al., 2016; DiLeo \& Wagner, 2016), although tropical organisms have been rarely assessed (Storfer et al., 2010a).

Even though the effects of habitat loss and fragmentation on genetic diversity have been reviewed extensively (Aguilar et al., 2006, 2008; Keyghobadi, 2007; Vranckx et al., 2012; Lino et al., 2018; Schlaepfer et al., 2018), there is an important knowledge gap regarding general landscape effects on gene flow (DiLeo \& Wagner, 2016). By influencing the willingness of an organism to cross a particular environment and the physiological or fitness costs of moving through it, the resistance imposed by landscape structure on the dispersal of organisms can 
79 ultimately affect genetic differentiation and patterns of gene flow (Zeller, McGarigal \& Whiteley,

80 2012; Balkenhol et al., 2016). To understand which landscape features impose a greater resistance

81 on gene flow, landscape geneticists first create resistance surfaces for landscape variables of

82 interest, then use these surfaces to estimate cost or resistance distances between sampling

83 locations, and finally regress measures of gene flow on these resistance distances (Spear,

84 Cushman \& McRae, 2016). Significant associations between gene flow metrics and landscape

85 resistance distances are taken for evidence of isolation by resistance (IBR), and effect sizes can

86 be considered proxies of functional connectivity (Manel \& Holderegger, 2013b).

87 Understanding the factors underpinning functional connectivity across species is essential

88 to design ecological corridors, identify conservation units, assess population threat status,

89 optimize pathogen and invasive species management, assist planning of natural heritage systems,

90 and restore threatened populations (Bowman et al., 2016; Waits LP, Cushman SA, 2016).

91 However, no efforts have yet been made to gather, standardize and compare IBR effects across

92 studies and organisms. For instance, landscape genetics is still a your field of research (Manel \&

93 Holderegger, 2013b), and the vast majority of landscape genetic studies have focused in a single

94 species (DiLeo \& Wagner, 2016; Waits LP, Cushman SA, 2016). So far, gene flow has been

95 shown to be influenced by various factors, including forest cover, land cover, topography, roads,

96 rivers, and climate, but responses vary greatly across species and units of analysis (populations or

97 individuals; see Balkenhol et al. 2016 and references therein).

98 Aiming to unravel the main drivers of functional connectivity in tropical landscapes, here

99 we compiled all studies that assessed landscape effects on gene flow in tropical species so far. To

100 our knowledge, this work represents the first quantitative comparison of such effects across

101 species and units of analysis. We believe this systematic review can help characterize the current

102 knowledge gap on tropical biodiversity responses to habitat degradation, and thereby highlight

103 future research needs.

104

105 Survey Methodology

106 Dataset

107 We employed the following search engines to perform a recursive literature search of landscape

108 effects on gene flow in tropical species published by June 2018: Scielo (http://www.scielo.org),

109 Portal de Periódicos da Coordenação de Aperfeiçoamento de Pessoal de Nível Superior do

110 Ministério da Educação (CAPES/MEC) (http://www.periodicos.capes.gov.br/); Google Scholar

111 (http://www.scholar.google.com.br); Web of Knowledge (http://www.isiknowledge.com), and 
112 Scopus (http://www.scopus.com). We used the following combination of keywords and Boolean

113 operators: ("landscape resistance" or landscape or resistance or fragmentation or "land use" or

114 "habitat loss" or deforestation) and (genetic* or "genetic differentiation" or "gene flow" or

115 "genetic distance" or FST or relatedness or kinship). Articles containing at least one of the

116 keywords on each side of the "and" operator were analyzed along with the relevant references

117 therein. Even though this search approach may not be easily replicated (as it involves a

118 substantial effort), it is more likely to minimize omissions than approaches based on the results

119 obtained from search engines alone. We then identified those studies that explicitly related

120 landscape with gene flow metrics in organisms collected between the tropics of Cancer and

121 Capricorn $\left(23.5^{\circ}\right.$ north and south of the equator) or within $200 \mathrm{~km}$ from them. Articles addressing

122 only isolation by geographic distance (IBD) were excluded, as our aim was to survey studies that

123 specifically incorporated landscape effects on gene flow in addition to geographic distance. We

124 then gathered all available information on the study objectives, focus species, study site,

125 ecosystem, the extent of the study area, the unit of analysis employed, sample size, types and

126 number of genetic markers employed, genetic and landscape resistance metrics employed,

127 statistical methods, landscape or environmental predictors assessed, and the effects reported.

\section{Comparing landscape effects on gene flow across studies}

130 We performed both qualitative and quantitative comparisons of landscape effects on gene flow

131 across studies. For the former, we grouped studies by the landscape or environmental factors

132 assessed and the focus taxonomic group, and summarized the reported effects on gene flow. For

133 the quantitative comparison we selected a subset of our dataset containing only studies that: i)

134 Explicitly reported correlation or regression coefficients, calculated from at least three samples,

135 and ii) Employed nuclear microsatellite markers to measure gene flow, given that measures of

136 genetic differentiation obtained with different genetic markers are not directly comparable across

137 studies (Wan et al., 2004; Allendorf, Luikart \& Aitken, 2013). We then separated the studies

138 fulfilling these requirements in two groups according to the units of analysis employed: Those

139 using population-level metrics of genetic differentiation $\left(F_{S T}\right.$ or $\left.D_{e s t}\right)$, and those using individual-

140 level metrics of genetic distance (Rousset's $a$, relatedness and kinship; Dataset S3). We note that

141 these genetic distance metrics should be considered surrogates of actual gene flow, as they reflect

142 the joint influence of genetic drift and dispersal (Prunier et al., 2017). An effect size approach

143 was used to compare isolation by resistance (IBR) within both types of studies (individual and 
144 population-level). Correlation coefficients were first normalized using the Fisher's z-

145 transformation (z), and standard errors (se) were calculated as following:

$147 \quad \mathrm{z}=\frac{1}{2} \ln \left(\frac{1+\mathrm{r}}{1-r}\right)$

148 se $=\frac{1}{\sqrt{N-3}}$ comparisons (between individuals or populations). Effect sizes were then calculated dividing the normalized correlation coefficients and standard errors (z/se) (Ellis, 2010). Effect sizes of regression coefficients were calculated dividing them by their respective standard errors. To facilitate comparisons between population-level and individual-level metrics of genetic differentiation we inverted the sign of relatedness and kinship estimates, thus representing genetic dissimilarity. We also calculated $95 \%$ confidence intervals for all effect sizes and retrieved the statistical significance ( $p$-values) of IBR effects reported in the original studies. We note that effect sizes were only used for comparative purposes, and that as in previous reviews (DiLeo \& Wagner, 2016), small sample sizes did not allow performing a formal meta-analysis.

\section{Results}

162 We found a total of 69 articles assessing landscape effects on gene flow in tropical organisms

163 (Dataset S1 in Supplemental Information), most of which were undertaken in the Americas (Fig.

164 1). We recorded 154 target species belonging to eight major taxonomic groups, from which

165 amphibians contained the largest number of species and mammals the highest number of papers

166 (Fig. 2). Most focus species were terrestrial and only three exclusively aquatic species were evaluated. The majority of studies analyzed a single species, but nine publications evaluated two or more. Three studies contributed with more than $40 \%$ of all recorded species (Wang, Glor $\&$ Losos, 2013; Paz et al., 2015; Jaffé et al., 2016). The oldest study found in our literature search (Trénel et al., 2008) investigated the impact of contemporary Andean landscape features on the spatial genetic structure of a palm tree. After this work, we observed a jump in the number of 172 publications from 2013 onward (Fig. 3).

173 The surveyed studies often had overlapping objectives, which comprised assessing 
175 Barahona \& Eguiarte, 2014); predicting gene flow with habitat suitability models (Poelchau \&

176 Hamrick, 2012; Guarnizo \& Cannatella, 2013; Paz et al., 2015); assessing landscape and climatic

177 effects on gene flow (Hohnen et al., 2016; Lanes et al., 2018); identifying dispersal routes

178 (Andraca-Gómez et al., 2015; Cleary, Waits \& Finegan, 2017; Thatte et al., 2018) and barriers to

179 gene flow (Robertson, Duryea \& Zamudio, 2009; Boff et al., 2014; Oliveira et al., 2017); and

180 evaluating the impact of habitat fragmentation on gene flow (Balkenhol et al., 2013; Joshi et al.,

181 2013; de Campos Telles et al., 2014; Carvalho et al., 2015; Ruiz-Lopez et al., 2015).

182 Five types of molecular markers were found across all studies (Fig. 4), and only five

183 publications used more than one type of marker (usually microsatellites and mtDNA).

184 Microsatellites were the most frequently used markers, with more studies using them than

185 publications using all other markers combined. More than $70 \%$ of all studies were performed at

186 the population-level and only five studies used both population and individual-level approaches

187 (Dataset S1). Electrical resistance (ER) was the most common resistance metric employed

188 (McRae, 2006), and Mantel and partial Mantel test the most common statistical methods used to

189 relate genetic with resistance distances (Fig. 5).

190 Landscape and environmental predictors of gene flow included elevation (altitude, terrain

191 ruggedness and slope), land cover, forest cover, habitat suitability (derived from species

192 distribution models), water (rivers, streams and the ocean), precipitation, roads and temperature

193 (Fig. 6, Dataset S1). Only six out of 22 studies considering elevation, four out of 22 studies

194 evaluating land cover, four out of 21 studies assessing forest cover, and 14 out of 17 studies

195 relying on habitat suitability models reported an effect on gene flow (Table S1). Most plant and

196 amphibian studies used habitat suitability models to generate resistance surfaces, but no

197 amphibian study analyzed forest cover, precipitation, roads or temperature independently; no bird

198 study used habitat suitability models; no plant study assessed the effect of water bodies; no reptile

199 or plant study addressed the effect of roads; and no mammal study considered temperature (Fig.

200 6).

201 The effect of habitat loss on gene flow was assessed in 25 studies and 39 species (Dataset

202 S2). From these, only 14 studies detected a reduction of gene flow with increasing habitat loss in

203 three plants, five mammals, one amphibian, two birds and one insect. Remarkably, most insects

204 were unaffected by habitat loss. Only 11 articles reported microsatellite-based IBR effects,

205 comprising 25 species (Dataset S3). Whereas IBD drove most significant effects across this group

206 of studies, individual-level studies ( $\mathrm{N}=14$ effects; Fig. 7) showed larger effect sizes than

207 population-level ones $(\mathrm{N}=78$ effects; Fig. 8). Two individual-level IBR effects were significant 
208 (revealing isolation by elevation in a bird and an ant, Fig. 7), and three significant IBR effects

209 were identified in population-level studies (revealing isolation by elevation in a plant and a bee,

210 and isolation by non-forested areas in an ant, Fig. 8).

211

\section{Discussion}

213 Despite the extraordinary levels of biological diversity comprised in the tropics, the study of

214 landscape effects on gene flow in tropical organisms only began to gain general attention in the

215 past five years. Still, published studies are mainly concentrated in the Americas and most of them

216 have focused on amphibians or mammals. The majority of studies were performed at the

217 population-level, electrical resistance was the most common resistance metric employed,

218 microsatellites were the most frequently employed type of molecular marker, and Mantel and

219 partial Mantel tests the most common statistical approaches used. While elevation, land cover and

220 forest cover were the most common gene flow predictors assessed, habitat suitability was found

221 to be a common predictor of gene flow. A third of all surveyed studies explicitly assessed the

222 effect of habitat degradation on gene flow, and only 14 studies detected a reduced gene flow with

223 increasing habitat loss. Finally, individual-level microsatellite-based IBR effects showed higher

224 effect sizes than population-level ones, elevation was responsible for most significant effects and

225 a single study reported significant isolation by non-forested areas in an ant.

226 One of the main aims of the field of landscape genetics has been to understand how landscape

227 characteristics shape patterns of functional connectivity (Manel \& Holderegger, 2013b), a subject

228 that has been addressed by many studies undertaken in temperate regions (Balkenhol et al.,

229 2016). Here we show that the study of landscape effects on gene flow in tropical organisms has

230 lagged behind, and that published studies are concentrated in the Americas, as are general

231 research effort on biodiversity in human-modified tropical forests (Gardner et al., 2009;

232 Schlaepfer et al., 2018). Moreover, we found that amphibians and mammals were over

233 represented in our surveyed studies, and most studies outside the Americas focused on mammals

234 (Figs. 1 and 2), reflecting taxonomic biases in biodiversity data and societal preferences (Troudet

235 et al., 2017). Our results thus highlight how little we still understand about landscape effects on

236 gene flow in the tropics, and call for more studies on unrepresented taxonomic groups, tropical

237 areas outside the Americas, and exclusively aquatic organisms.

238 Most of the surveyed studies used microsatellite markers, despite the not so recent shift

239 towards genotyping by sequencing (GBS) triggered by next generation sequencing technologies

240 (Allendorf, Hohenlohe \& Luikart, 2010; Benestan et al., 2016). For instance, microsatellite 
241 genotyping is still cheaper than GBS, and cross-amplification of SSR markers in related species

242 often reduces the cost of developing species-specific markers (Storfer et al., 2010b). However,

243 SNPs are rapidly becoming the new standard in population and landscape genomic studies, due to

244 their genome-wide coverage and analytical simplicity (Morin, Luikart \& Wayne, 2004).

245 Moreover, sequencing costs have fallen dramatically (Shendure et al., 2017), and GBS

246 approaches (such as RAD-sequencing) allow an affordable high-coverage sequencing of a

247 representation of the genome and the discovery of thousands of SNPs in organisms lacking a

248 reference genome (Rowe, Renaut \& Guggisberg, 2011; Hohenlohe, Catchen \& Cresko, 2012).

249 Perhaps the most important obstacle preventing the widespread adoption of GBS is the

250 complexity of bioinformatic processing (pre-processing of sequence data) and working with very

251 large datasets (Johnson, 2009), but we believe that a much higher resolution coupled with the

252 possibility to study both neutral and adaptive genetic variation are worth the effort (Rodriguez et

253 al., 2015; Lanes et al., 2018).

254 Electrical resistance was the most common resistance metric employed, revealing its ample

255 adoption as a general predictor of animal and plant gene flow (McRae \& Beier, 2007).

256 Additionally, we found that Mantel and partial Mantel tests were the most widely used statistical

257 approaches to relate landscape and environmental characteristics with gene flow, even though

258 better methods are available (Prunier et al., 2015; Richardson et al., 2016). The limitations of

259 Mantel tests have been thoroughly discussed (Guillot \& Rousset, 2013; Zeller et al., 2016), and

260 include high type-I error rates (i.e. false positives), the inability to model the effect of multiple

261 covariates simultaneously (as in a multiple regression), and the absence of a maximum-likelihood

262 framework that allows for model selection (Shirk et al., 2010; Shirk, Landguth \& Cushman,

263 2018). Maximum likelihood population effects (MLPE) are particularly appealing mixed-effects

264 models for use landscape genetic studies because they allow implementing multiple regressions

265 that account for the non-independence of pairwise distances within a likelihood framework

266 (Clarke, Rothery \& Raybould, 2002) compatible with model selection based on information

267 criteria such as AIC (Jaffé et al., 2016; Row et al., 2017; Shirk, Landguth \& Cushman, 2018).

268 Most surveyed studies assessed gene flow responses to few landscape and environmental

269 variables, from which elevation, land cover and forest cover were the most common. For

270 instance, no plant study assessed the effect of water bodies; no reptile or plant study addressed

271 the effect of roads; and no mammal study considered temperature. Again, these finding suggest

272 data and societal preferences (Troudet et al., 2017), although the more limited availability of

273 environmental layers in tropical compared with temperate regions must be highlighted too. 
274 Making available more spatially explicit environmental data in the tropics could certainly help

275 broaden the scope of future efforts to capture landscape effects on gene flow (Collen et al., 2008;

276 Barlow et al., 2018). The surveyed studies were nevertheless able to quantify functional

277 connectivity (Balkenhol et al., 2013; Carvalho et al., 2015; Ruiz-Lopez et al., 2015), propose

278 ecological corridors (Atickem et al., 2013; Yumnam et al., 2014), assess threat status (Lanes et

279 al., 2018), evaluate restoration effectiveness (Moraes et al., 2018), and forecast the impact of

280 future climate and environmental changes on gene flow (Thomassen et al., 2009; Velo-Antõn et

281 al., 2013; Thatte et al., 2018). Interestingly, several studies found an effect of habitat suitability

282 on gene flow, suggesting that habitat suitability models are useful when proposing ecological

283 corridors or forecasting the impact of future climate on gene flow (Franklin \& Miller, 2009),

284 although habitat suitability does not always reflect permeability for dispersal (Mateo-Sánchez et

285 al., 2015). Additionally, elevation was responsible for most significant microsatellite-based IBR

286 effects (Figs. 7 and 8), a result that suggests elevation is an important mediator of functional

287 connectivity in tropical landscapes (Worboys, Francis \& Lockwood, 2010).

288 Despite global concerns with the negative effects of habitat degradation on tropical

289 biodiversity (Barlow et al., 2018), only 25 studies have so far explicitly assessed the effect of

290 habitat degradation on gene flow. From these, only 14 found reduced gene flow with increasing

291 habitat loss, and a single microsatellite-based study reported a significant isolation by non-

292 forested areas in an army ant (Fig. 8). In contrast to other flying insects where both females and

293 males disperse, army ant queens are permanently wingless, so gene flow is restricted and mainly

294 driven by male dispersal (Jaffé, Moritz \& Kraus, 2009; Pérez-Espona, McLeod \& Franks, 2012).

295 These findings suggest that the effect of habitat loss on gene flow is difficult to detect, as species

296 with extremely restricted dispersal are more likely to show large effect sizes and thus be less

297 susceptible to type-II errors (false negatives).

298 Many sources of variation could have influenced the detection of landscape effects on gene

299 flow, including species-specific differences in dispersal ability and reproductive systems,

300 historical processes underpinning genetic differentiation, different sample sizes, the resolution of

301 the spatial data (grain size), the extent of the study area, sampling design, and time-lags in the

302 responses to landscape changes (Anderson et al., 2010; Balkenhol et al., 2016; Schlaepfer et al.,

303 2018). However, small sample sizes, limited information on the natural history of most studied

304 species and inconsistencies in the way data was reported across studies preclude a quantitative

305 assessment of the impact of these factors on our observed effect sizes (Dataset S3). Even though

306 the majority of the surveyed studies employed population-level approaches, individual-level 
307 studies showed higher effect sizes, a finding that reinforces that individual-level analyses based

308 on continuously distributed samples are more powerful and appropriate for landscape genetic

309 studies (Landguth et al., 2010; Balkenhol et al., 2016). Additionally, studies that account for the

310 underlying population structure or inter-population variations in effective population size $(\mathrm{Ne})$ are

311 more likely disentangle landscape from drift effects on gene flow (Prunier et al., 2017). This is

312 because population-level metrics of genetic connectivity like the frequently used $F_{S T}$ actually

313 measures the balance between genetic drift on the one hand, and migration on the other. To the

314 best of our knowledge, none of the analyzed studies accounted for variations in $\mathrm{Ne}$ between

315 sample units when modeling IBR. This can be done by employing different distance metrics

316 [such as conditional genetic distance (Dyer, Nason \& Garrick, 2010)], by restricting IBR models

317 to sample units belonging to the same genetic cluster (i.e. with the same $\mathrm{Ne}$ ), by including a

318 random effect specifying the nature of pairwise genetic distances (from sample units belonging to

319 the same or different genetic clusters), or through gravity models that explicitly incorporate $\mathrm{Ne}$ or

320 other node-level proxy of population size (DiLeo \& Wagner, 2016; Zero et al., 2017).

\section{Conclusions}

323 Our study reveals important knowledge gaps regarding landscape effects on gene flow in tropical 324 organisms, which prevent making cross-species generalizations. However, general patterns of 325 genetic connectivity provide important insights into common barriers to gene flow or responses 326 to land use changes (Poelchau \& Hamrick, 2012; Wang, Glor \& Losos, 2013; Paz et al., 2015;

327 Jaffé et al., 2016; Lanes et al., 2018). Such knowledge is particularly important to inform

328 conservation actions seeking to safeguard ecosystem function, and not only target species (Manel $329 \&$ Holderegger, 2013b). Our work nevertheless provides some useful guidelines to help fill these

330 knowledge gaps: 1) Increased efforts are needed to study unrepresented taxonomic groups and

331 tropical areas outside the Americas, as well as generate more spatially explicit environmental data

332 in the tropics; 2) The adoption of genotyping by sequencing and individual-level approaches

333 could substantially increase statistical power and shed light into both neutral and adaptive

334 patterns of genetic variation; 3) Using mixed effect MLPE models to relate genetic and spatial

335 data, could minimize type-I errors, result in more accurate parameter estimates (which account

336 for multiple landscape and environmental predictors), and help establish a common model-

337 selection framework across landscape genetic studies (Row et al., 2017; Shirk, Landguth \&

338 Cushman, 2018); 4) Explicitly modeling the impact of historical processes underpinning genetic

339 differentiation, the resolution of the spatial data, and possible time-lags (DiLeo \& Wagner, 2016; 
340 Waits LP, Cushman SA, 2016), could help provide more confidence in landscape effects on gene

341 flow and make IBR estimates comparable across studies.

342

343 Acknowledgments

344 We thank Nathaniel S. Pope for statistical support, Flora Bittencourt, Gabriela Schmaedecke and

345 two anonymous referees for improving earlier versions of this manuscript.

346

347 Supplemental Information

348 Supplemental Datasets.

349 
350

351

352

353

354

355

356

357

358

359

360

361

362

363

364

365

366

367

368

369

370

371

372

373

374

375

376

377

378

379

380

381

382

383

384

385

\section{References}

Aguilar R., Ashworth L., Galetto L., Aizen MA. 2006. Plant reproductive susceptibility to habitat fragmentation: Review and synthesis through a meta-analysis. Ecology Letters 9:968-980. DOI: 10.1111/j.1461-0248.2006.00927.x.

Aguilar R., Quesada M., Ashworth L., Herrerias-Diego Y., Lobo J. 2008. Genetic consequences of habitat fragmentation in plant populations: Susceptible signals in plant traits and methodological approaches. Molecular Ecology 17:5177-5188. DOI: 10.1111/j.1365294X.2008.03971.x.

Allendorf FW., Hohenlohe PA., Luikart G. 2010. Genomics and the future of conservation genetics. Nature Reviews Genetics 11:697-709. DOI: 10.1038/nrg2844.

Allendorf FW., Luikart GH., Aitken SN. 2013. Conservation and the genetics of populations. Oxford: Wiley-Blackwell.

Anderson CD., Epperson BK., Fortin MJ., Holdergger R., James P., Rosenberg MS., Scribner KIMT., Spear S. 2010. Considering spatial and temporal scale in landscape $\square$ genetic studies of gene flow. Molecular Ecology 19:3565-3575.

Andraca-Gómez G., Ordano M., Boege K., Domínguez CA., Piñero D., Pérez-Ishiwara R., PérezCamacho J., Cañizares M., Fornoni J. 2015. A potential invasion route of Cactoblastis cactorum within the Caribbean region matches historical hurricane trajectories. Biological Invasions 17:1397-1406. DOI: 10.1007/s10530-014-0802-2.

Atickem A., Rueness EK., Loe LE., Serbezov D., Bekele A., Stenseth NC. 2013. Population genetic structure and connectivity in the endangered Ethiopian mountain Nyala (Tragelaphus buxtoni): Recommending dispersal corridors for future conservation. Conservation Genetics 14:427-438. DOI: 10.1007/s10592-013-0450-6.

Balkenhol N., Cushman SA., Waits LP., Storfer A. 2016. Landscape Genetics: Concepts, Methods, Applications. Hoboken, NJ: John Wiley \& Sons.

Balkenhol N., Pardini R., Cornelius C., Fernandes F., Sommer S. 2013. Landscape-level comparison of genetic diversity and differentiation in a small mammal inhabiting different fragmented landscapes of the Brazilian Atlantic Forest. Conservation Genetics 14:355-367. DOI: $10.1007 / \mathrm{s} 10592-013-0454-2$.

Barlow J., França F., Gardner TA., Hicks CC., Lennox GD., Berenguer E., Castello L., Economo EP., Ferreira J., Guénard B., Gontijo Leal C., Isaac V., Lees AC., Parr CL., Wilson SK., Young PJ., Graham NAJ. 2018. The future of hyperdiverse tropical ecosystems. Nature 559:517-526. DOI: 10.1038/s41586-018-0301-1.

Benestan LM., Ferchaud A-L., Hohenlohe, A. P., Garner BA., Naylor GJP., Baums IB., Schwartz, K. M., Kelley JL., Luikart G. 2016. Conservation genomics of natural and managed 
386

387

388

389

390

391

392

393

394

395

396

397

398

399

400

401

402

403

404

405

406

407

408

409

410

411

412

413

414

415

416

417

418

419

420

populations: Building a conceptual and practical framework. Molecular Ecology 25:1-11. DOI: $10.1111 / \mathrm{mec} .13647$.

Boff S., Soro A., Paxton RJ., Alves-dos-Santos I. 2014. Island isolation reduces genetic diversity and connectivity but does not significantly elevate diploid male production in a neotropical orchid bee. Conservation Genetics 15:1123-1135. DOI: 10.1007/s10592-014-0605-0.

Bowman J., Greenhorn JE., Marrotte RR., McKay MM., Morris KY., Prentice MB., Wehtje M. 2016. On applications of landscape genetics. Conservation Genetics:1-8.

Bradshaw CJA., Sodhi NS., Brook BW. 2009. Tropical turmoil: A biodiversity tragedy in progress. Frontiers in Ecology and the Environment 7:79-87. DOI: 10.1890/070193.

Brown JH. 2014. Why are there so many species in the tropics? Journal of Biogeography 41:822. DOI: $10.1111 /$ jbi.12228.

de Campos Telles MP., Dobrovolski R., da Silva e Souza K., de Souza Lima J., Collevatti RG., Soares TN., Chaves LJ., Diniz-Filho JAF. 2014. Disentangling landscape effects on population genetic structure of a Neotropical savanna tree. Natureza \& Conservação 12:6570. DOI: $10.4322 /$ natcon.2014.012.

Carvalho C., Ribeiro MC., Côrtes MC., Galetti M., Collevatti RG. 2015. Contemporary and historic factors influence differently genetic differentiation and diversity in a tropical palm. Heredity 115:216-224. DOI: 10.1038/hdy.2015.30.

Clarke RT., Rothery P., Raybould AF. 2002. Confidence limits for regression relationships between distance matrices: Estimating gene flow with distance. Journal of Agricultural, Biological, and Environmental Statistics 7:361-372. DOI: 10.1198/108571102320.

Clarke DA., York PH., Rasheed MA., Northfield TD. 2017. Does Biodiversity-Ecosystem Function Literature Neglect Tropical Ecosystems? Trends in Ecology \& Evolution 32:320323. DOI: 10.1016/j.tree.2017.02.012.

Cleary KA., Waits LP., Finegan B. 2017. Comparative landscape genetics of two frugivorous bats in a biological corridor undergoing agricultural intensification. Molecular Ecology 26:46034617. DOI: $10.1111 / \mathrm{mec} .14230$.

Collen B., Ram M., Zamin T., McRae L. 2008. The Tropical Biodiversity Data Gap: Addressing Disparity in Global Monitoring. Tropical Conservation Science. DOI: 10.1177/194008290800100202.

Devictor V., Julliard R., Jiguet F. 2008. Distribution of specialist and generalist species along spatial gradients of habitat disturbance and fragmentation. Oikos. DOI: 10.1111/j.00301299.2008.16215.x.

DiLeo MF., Wagner HH. 2016. A Landscape Ecologist's Agenda for Landscape Genetics. Current Landscape Ecology Reports:1-12. DOI: 10.1007/s40823-016-0013-x. 
421 Dyer RJ., Nason J., Garrick RC. 2010. Landscape modelling of gene flow: improved power using conditional genetic distance derived from the topology of population networks. Molecular Ecology 19:3746-3759. DOI: 10.1111/j.1365-294X.2010.04748.x.

Ehrlén J., Morris WF. 2015. Predicting changes in the distribution and abundance of species under environmental change. Ecology Letters. DOI: 10.1111/ele.12410.

Ellis PD. 2010. The Essential Guide to Effect Sizes : An Introduction to Statistical Power, MetaAnalysis and the Interpretation of Research Results. Cambridge University Press.

Franklin J., Miller JA. 2009. Mapping species distributions: Spatial inference and prediction. New Yorl: Cambridge University Press. DOI: 10.1017/CBO9780511810602.

Gardner TA., Barlow J., Chazdon R., Ewers RM., Harvey CA., Peres CA., Sodhi NS. 2009. Prospects for tropical forest biodiversity in a human-modified world. Ecology Letters. DOI: 10.1111/j.1461-0248.2009.01294.x.

Guarnizo CE., Cannatella DC. 2013. Genetic divergence within frog species is greater in topographically more complex regions. Journal of Zoological Systematics and Evolutionary Research 51:333-340. DOI: 10.1111/jzs.12027.

Guillot G., Rousset F. 2013. Dismantling the Mantel tests. Methods in Ecology and Evolution 4:336-344. DOI: 10.1111/2041-210x.12018.

Hohenlohe P., Catchen J., Cresko W. 2012. Population Genomic Analysis of Model and Nonmodel Organisms Using Sequenced RAD Tags. In: Pompanon F, Bonin A eds. Data Production and Analysis in Population Genomics. Humana Press, 235-260. DOI: 10.1007/978-1-61779-870-2_14.

Hohnen R., D. Tuft K., Legge S., Hillyer M., Spencer PBS., J. Radford I., Johnson CN., Burridge CP. 2016. Rainfall and topography predict gene flow among populations of the declining northern quoll (Dasyurus hallucatus). Conservation Genetics 17:1213-1228. DOI: 10.1007/s10592-016-0856-Z.

Jackson ST., Sax DF. 2009. Balancing biodivesity in a changing environment: extinction debt, immigration credit and species turnover. Trends in Ecology and Evolution.

Jaffé R., Moritz RFA., Kraus FB. 2009. Gene flow is maintained by polyandry and male dispersal in the army ant Eciton burchellii. Population Ecology 51:227-236. DOI: 10.1007/s10144008-0133-1.

Jaffé R., Pope N., Acosta AL., Alves DA., Arias MC., De la Rúa P., Francisco FO., Giannini TC., González-Chaves A., Imperatriz-Fonseca VL., Tavares MG., Jha S., Carvalheiro LG. 2016. Beekeeping practices and geographic distance, not land use, drive gene flow across tropical bees. Molecular Ecology 25:5345-5358. DOI: 10.1111/mec.13852. 
455

456

457

458

459

460

461

462

463

464

465

466

467

468

469

470

471

472

473

474

475

476

477

478

479

480

481

482

483

484

485

486

487

488

489

490

Johnson AD. 2009. Single-Nucleotide Polymorphism Bioinformatics: A Comprehensive Review of Resources. Circulation: Cardiovascular Genetics 2:530-536. DOI: 10.1161/CIRCGENETICS.109.872010.

Joshi A., Vaidyanathan S., Mondo S., Edgaonkar A., Ramakrishnan U. 2013. Connectivity of tiger (Panthera tigris) populations in the human-influenced forest mosaic of central India. PLoS ONE 8. DOI: 10.1371/journal.pone.0077980.

Keyghobadi N. 2007. The genetic implications of habitat fragmentation for animals. Canadian Journal of Zoology 85:1049-1064. DOI: 10.1139/Z07-100.

Landguth EL., Cushman SA., Schwartz MK., McKelvey KS., Murphy M., Luikart G. 2010. Quantifying the lag time to detect barriers in landscape genetics. Molecular Ecology 19:4179-4191. DOI: 10.1111/j.1365-294X.2010.04808.x.

Lanes ÉC., Pope NS., Alves R., Carvalho Filho NM., Giannini TC., Giulietti AM., ImperatrizFonseca VL., Monteiro W., Oliveira G., Silva AR., Siqueira JO., Souza-Filho PW., Vasconcelos S., Jaffé R. 2018. Landscape genomic conservation assessment of a narrowendemic and a widespread morning glory from amazonian savannas. Frontiers in Plant Science 9. DOI: 10.3389/fpls.2018.00532.

Lino A., Fonseca C., Rojas D., Fischer E., Ramos Pereira MJ. 2018. A meta-analysis of the effects of habitat loss and fragmentation on genetic diversity in mammals. Mammalian Biology. DOI: https://doi.org/10.1016/j.mambio.2018.09.006.

Manel S., Holderegger R. 2013a. Ten years of landscape genetics. Trends in Ecology and Evolution 28:614-621. DOI: 10.1016/j.tree.2013.05.012.

Manel S., Holderegger R. 2013b. Ten years of landscape genetics. Trends in Ecology and Evolution 28:614-621. DOI: 10.1016/j.tree.2013.05.012.

Mateo-Sánchez MC., Balkenhol N., Cushman S., Pérez T., Domínguez A., Saura S. 2015. A comparative framework to infer landscape effects on population genetic structure: are habitat suitability models effective in explaining gene flow? Landscape Ecology 30:14051420. DOI: 10.1007/s10980-015-0194-4.

McRae BH. 2006. Isolation by resistance. Evolution 60:1551-1561. DOI: 10.1111/j.00143820.2006.tb00500.x.

McRae BH., Beier P. 2007. Circuit theory predicts gene flow in plant and animal populations. Proceedings of the National Academy of Sciences 104:19885-19890. DOI: 10.1073/pnas.0706568104.

Moraes AM., Ruiz C., Jr PG., Niebuhr BBS., Alexandre B., Muylaert RL., Grativol A., Ribeiro JW., Ferreira AN., Ribeiro MC. 2018. Landscape resistance influences effective dispersal of endangered golden lion tamarins within the Atlantic Forest. Biological Conservation 224:023. DOI: $10.1017 / \mathrm{S} 0950268817001236$. 
491 Morin PJ. 2009. Community ecology. John Wiley \& Sons.

492 Morin PA., Luikart G., Wayne RK. 2004. SNPs in ecology, evolution and conservation. Trends in 493 Ecology and Evolution 19:208-216. DOI: 10.1016/j.tree.2004.01.009.

Myers N., Mittermeier RA., Mittermeier CG., da Fonseca GAB., Kent J. 2000. Biodiversity 495 hotspots for conservation priorities. Nature 403:853-858. DOI: 10.1038/35002501.

Oliveira EF., Martinez PA., São-Pedro VA., Gehara M., Burbrink FT., Mesquita DO., Garda AA., 497 Colli GR., Costa GC. 2017. Climatic suitability, isolation by distance and river resistance explain genetic variation in a Brazilian whiptail lizard. Heredity 120:251-265. DOI: 10.1038/s41437-017-0017-2.

Paz A., Ibáñez R., Lips KR., Crawford AJ. 2015. Testing the role of ecology and life history in structuring genetic variation across a landscape: A trait-based phylogeographic approach. Molecular Ecology 24:3723-3737. DOI: 10.1111/mec.13275.

Pérez-Espona S., McLeod JE., Franks NR. 2012. Landscape genetics of a top neotropical

505

506

507

508

509

510

511

512

513

514

515

516

517

518

519

520

521

522

523

524

525 predator. Molecular Ecology 21:5969-5985. DOI: 10.1111/mec.12088.

Poelchau MF., Hamrick JL. 2012. Differential effects of landscape-level environmental features on genetic structure in three codistributed tree species in Central America. Molecular Ecology 21:4970-4982. DOI: 10.1111/j.1365-294X.2012.05755.x.

Prunier JG., Colyn M., Legendre X., Nimon KF., Flamand MC. 2015. Multicollinearity in spatial genetics : separating the wheat from the chaff using commonality analyses. Molecular Ecology. DOI: 10.1111/mec.13029.

Prunier JG., Dubut V., Chikhi L., Blanchet S. 2017. Contribution of spatial heterogeneity in effective population sizes to the variance in pairwise measures of genetic differentiation. Methods in Ecology and Evolution 8:1866-1877. DOI: 10.1111/2041-210X.12820.

Ramírez-Barahona S., Eguiarte LE. 2014. Changes in the distribution of cloud forests during the last glacial predict the patterns of genetic diversity and demographic history of the tree fern Alsophila firma (Cyatheaceae). Journal of Biogeography 41:2396-2407. DOI: 10.1111/jbi.12396.

Richardson JL., Brady SP., Wang IJ., Spear SF. 2016. Navigating the pitfalls and promise of landscape genetics. Molecular ecology 25:849-863. DOI: 10.1111/mec.13527.

Robertson JM., Duryea MC., Zamudio KR. 2009. Discordant patterns of evolutionary differentiation in two Neotropical treefrogs. Molecular Ecology 18:1375-1395. DOI: 10.1111/j.1365-294X.2009.04126.x.

Rodriguez M., Rau D., Bitocchi E., Bellucci E., Biagetti E., Carboni A., Gepts P., Nanni L., Papa R., Attene G. 2015. Landscape genetics, adaptive diversity and population structure in Phaseolus vulgaris. New Phytologist 209:1781-1794. DOI: 10.1111/nph.13713. 
526 Row JR., Knick ST., Oyler-McCance SJ., Lougheed SC., Fedy BC. 2017. Developing approaches

527 for linear mixed modeling in landscape genetics through landscape-directed dispersal

528 simulations. Ecology and Evolution 7:3751-3761. DOI: 10.1002/ece3.2825.

529 Rowe HC., Renaut S., Guggisberg A. 2011. RAD in the realm of next-generation sequencing

530 technologies. Molecular Ecology 20:3499-3502. DOI: 10.1111/j.1365-294X.2011.05197.x.

531 Ruiz-Lopez MJ., Barelli C., Rovero F., Hodges K., Roos C., Peterman WE., Ting N. 2015. A

532 novel landscape genetic approach demonstrates the effects of human disturbance on the

533 Udzungwa red colobus monkey (Procolobus gordonorum). Heredity 116:167-176. DOI:

$534 \quad 10.1038 /$ hdy.2015.82.

535 Schlaepfer DR., Braschler B., Rusterholz H-P., Baur B. 2018. Genetic effects of anthropogenic

536 habitat fragmentation on remnant animal and plant populations: a meta-analysis. Ecosphere

537 9:e02488. DOI: 10.1002/ecs2.2488.

538 Shendure J., Balasubramanian S., Church GM., Gilbert W., Rogers J., Schloss JA., Waterston RH. 539 2017. DNA sequencing at 40: Past, present and future. Nature. DOI: 10.1038/nature24286.

540 Shirk AJ., Landguth EL., Cushman SA. 2018. A comparison of regression methods for model

541 selection in individual-based landscape genetic analysis. Molecular Ecology Resources

542 18:55-67. DOI: 10.1111/1755-0998.12709.

543 Shirk AJ., Wallin DO., Cushman SA., Rice CG., Warheit KI. 2010. Inferring landscape effects on gene flow: A new model selection framework. Molecular Ecology 19:3603-3619. DOI:

546 10.1111/j.1365-294X.2010.04745.x.

Spear SF., Cushman SA., McRae BH. 2016. Resistance surface modeling in landscape genetics. In: Balkenhol N, Cushman S, Storfer A, Waits L eds. Landscape Genetics: Concepts,

Storfer A., Murphy MA., Spear SF., Holderegger R., Waits LP. 2010a. Landscape genetics: where

Storfer A., Murphy MA., Spear SF., Holderegger R., Waits LP. 2010b. Landscape genetics: Where are we now? Molecular Ecology 19:3496-3514. DOI: 10.1111/j.1365294X.2010.04691.x.

Thatte P., Joshi A., Vaidyanathan S., Landguth E., Ramakrishnan U. 2018. Maintaining tiger connectivity and minimizing extinction into the next century_ Insights from landscape genetics and spatially-explicit simulations. Biological Conservation 218:181-191. DOI: 10.1016/j.biocon.2017.12.022.

559

Thomassen HA., Freedman AH., Brown DM., Buermann W., Jacobs DK. 2009. Modeling

560 environmentally associated morphological and genetic variation in a rainforest bird, and its

561 application to conservation prioritization. PLOS ONE 8. DOI: 10.1371/journal.pone.0077191. 
562 Trénel P., Hansen MM., Normand S., Borchsenius F. 2008. Landscape genetics, historical

563 isolation and cross-Andean gene flow in the wax palm, Ceroxylon echinulatum (Arecaceae).

564 Molecular Ecology 17:3528-3540. DOI: 10.1111/j.1365-294X.2008.03853.x.

565 Troudet J., Grandcolas P., Blin A., Vignes-Lebbe R., Legendre F. 2017. Taxonomic bias in

566 biodiversity data and societal preferences. Scientific Reports 7. DOI: 10.1038/s41598-017-

567 09084-6.

568 Velo-Antõn G., Parra JL., Parra-Olea G., Zamudio KR. 2013. Tracking climate change in a

569 dispersal-limited species: Reduced spatial and genetic connectivity in a montane salamander.

$570 \quad$ Molecular Ecology 22:3261-3278. DOI: 10.1111/mec.12310.

571 Vranckx G., Jacquemyn H., Muys B., Honnay O. 2012. Meta-Analysis of Susceptibility of

572 Woody Plants to Loss of Genetic Diversity through Habitat Fragmentation. Conservation

573 Biology 26:228-237. DOI: 10.1111/j.1523-1739.2011.01778.x.

574 Waits LP, Cushman SA SS. 2016. Applications of landscape genetics to connectivity research in

575 terrestrial animals. In: Landscape Genetics: Concepts, Methods, Applications. 199-219.

576 Wan QH., Wu H., Fujihara T., Fang SG. 2004. Which genetic marker for which conservation 577 genetics issue? Electrophoresis 25:2165-2176. DOI: 10.1002/elps.200305922.

578 Wang IJ., Glor RE., Losos JB. 2013. Quantifying the roles of ecology and geography in spatial 579 genetic divergence. Ecology Letters 16:175-182. DOI: 10.1111/ele.12025.

580 Worboys G., Francis WL., Lockwood M. 2010. Connectivity conservation management: a global 581 guide (with particular reference to mountain connectivity conservation). Earthscan.

582 Yumnam B., Jhala Y V., Qureshi Q., Maldonado JE., Gopal R., Saini S., Srinivas Y., Fleischer 583 RC. 2014. Prioritizing tiger conservation through landscape genetics and habitat linkages. $584 \quad$ PLOS ONE 9. DOI: 10.1371/journal.pone.0111207.

585 Zeller KA., Creech TG., Millette KL., Crowhurst RS., Long RA., Wagner HH., Balkenhol N., 586 Landguth EL. 2016. Using simulations to evaluate Mantel-based methods for assessing $587 \quad$ landscape resistance to gene flow. DOI: 10.1002/ece3.2154.

588 Zeller KA., McGarigal K., Whiteley AR. 2012. Estimating landscape resistance to movement: A 589 review. Landscape Ecology. DOI: 10.1007/s10980-012-9737-0.

590 Zero VH., Barocas A., Jochimsen DM., Pelletier A., Giroux-Bougard X., Trumbo DR., Castillo 591 JA., Evans Mack D., Linnell MA., Pigg RM., Hoisington-Lopez J., Spear SF., Murphy MA., 592 Waits LP. 2017. Complementary Network-Based Approaches for Exploring Genetic Structure and 593 Functional Connectivity in Two Vulnerable, Endemic Ground Squirrels. Frontiers in Genetics $5948: 81$.

595 
Figure 1

Sampling locations of the surveyed studies.

Taxonomic groups are indicated by colors and the unit of analysis by shapes (triangles indicate individual-level studies and circles population-level ones). Horizontal dotted lines represent the Tropic of Cancer, the Equator and the Tropic of Capricorn respectively, from North to South.

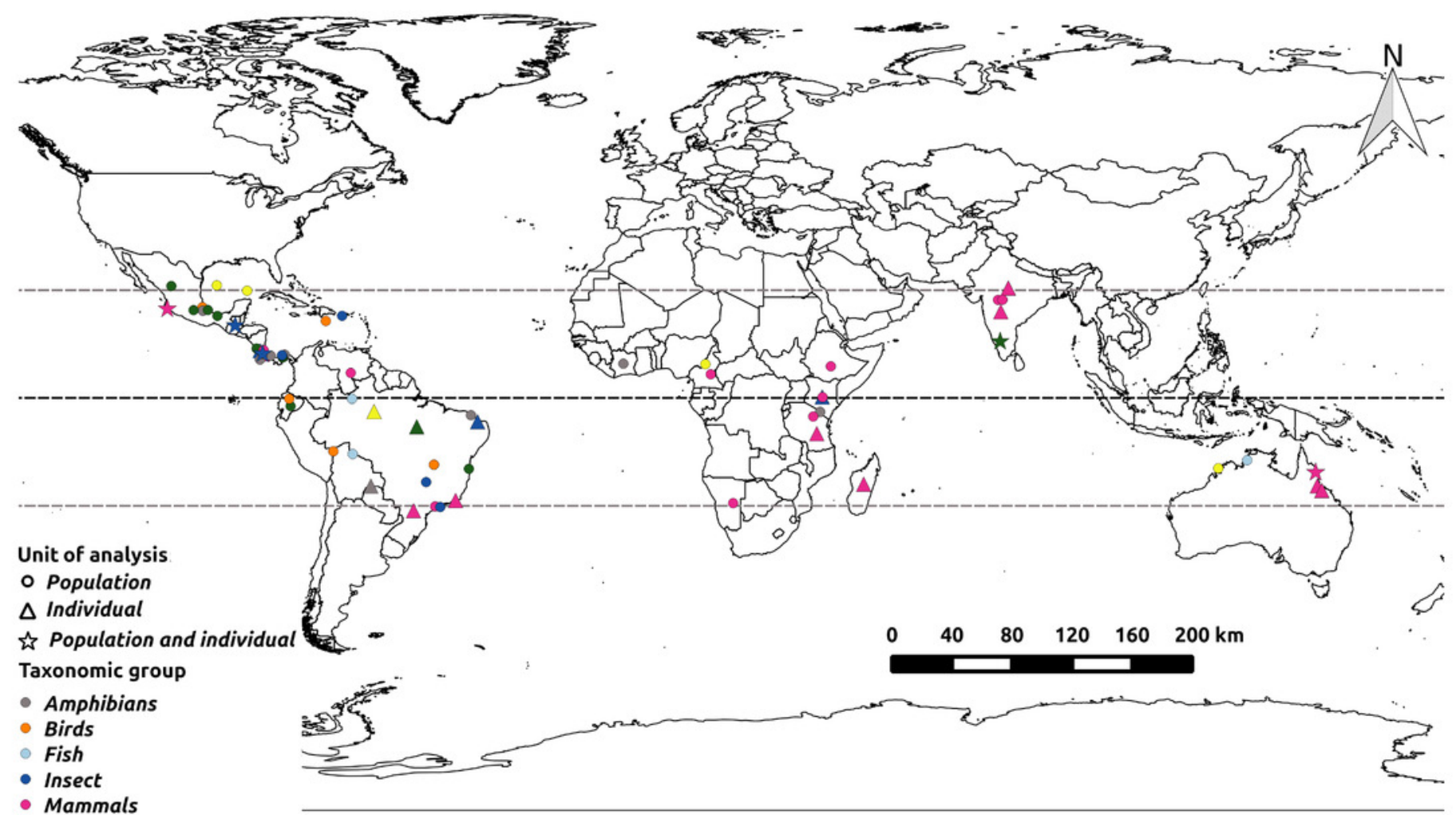

- Mammals

- Plants

Reptiles 
Figure 2

Number of species assessed and number of publications for each taxonomic group.

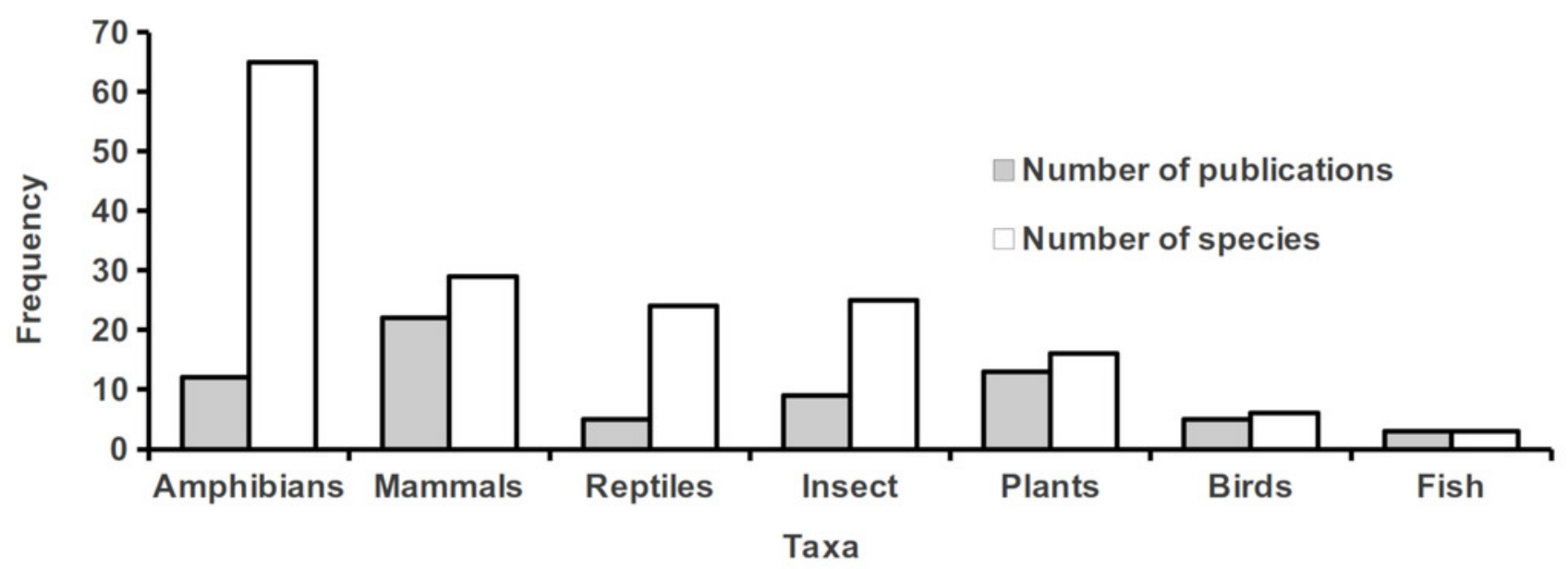


Figure 3

Number of studies assessing landscape effects on gene flow in tropical organisms, published between 2008 and 2018.

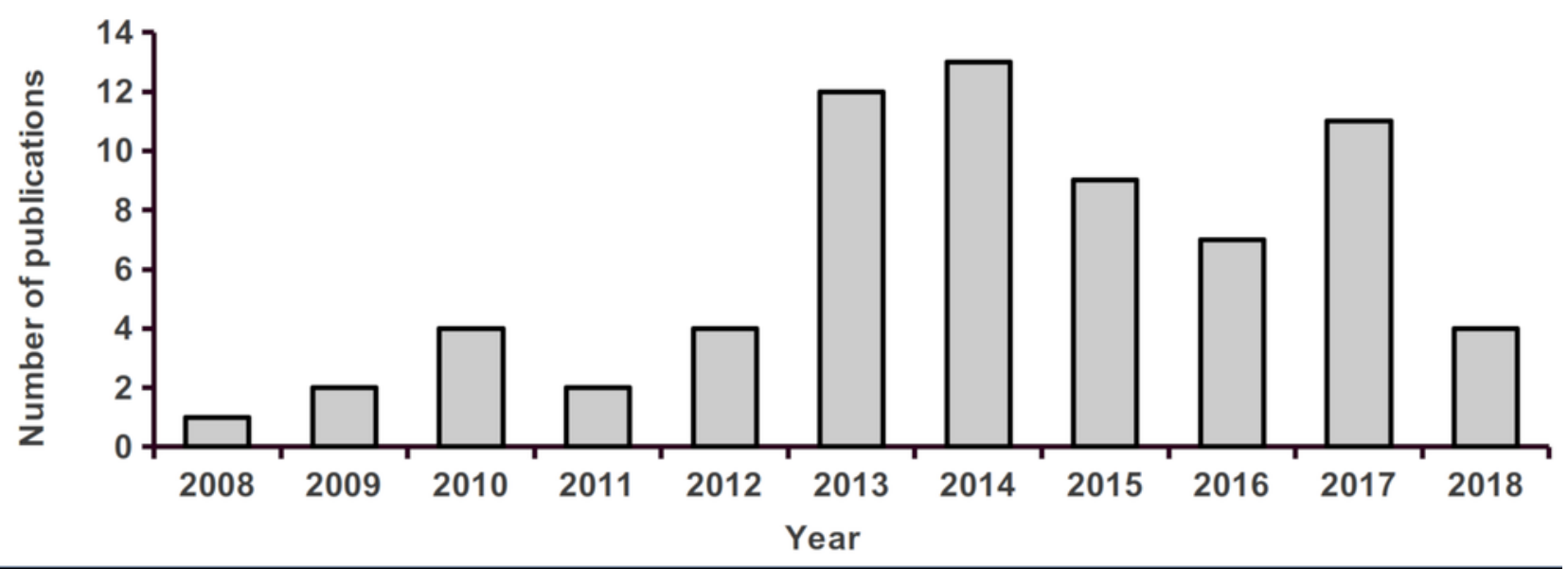




\section{Figure 4}

Proportion of studies using different types of genetic markers to assess landscape effects on gene flow in tropical organisms.

Microsatellites, AFLPs and SNPs refer to nuclear DNA. Mitochondrial DNA (mtDNA) and Chloroplast DNA (cpDNA) are specified as such.

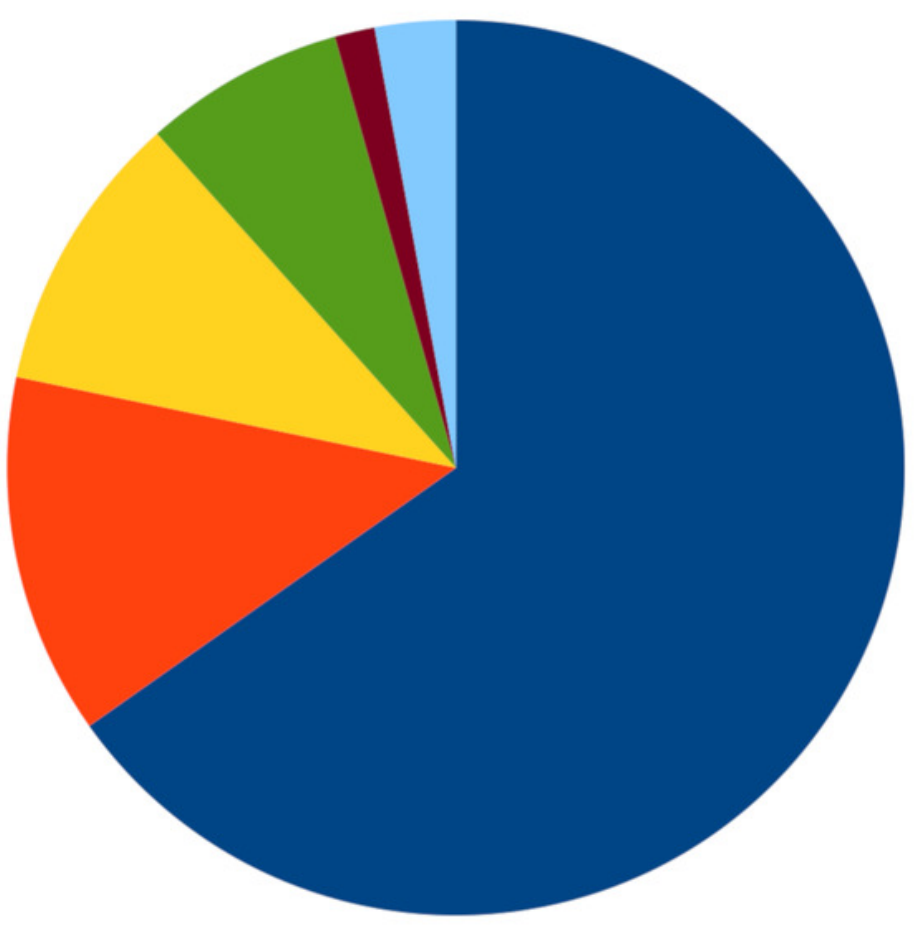

- Microsatellites

mtDNA

AFLP

mtDNA+Micros

- cpDNA

SNPS 


\section{Figure 5}

Number of studies using different statistical approaches to assess landscape effects on gene flow in tropical organisms.

Full methods names, by order of appearance on the figure are: Mantel and Partial Mantel tests, Maximum likelihood population effects (MLPE) models, generalized dissimilarity models (GDM), redundancy analyses (RDA), multiple regression on distance matrices (MRDM), generalized linear models (GLM), linear mixed-effect models (LMM), Monte Carlo permutation matrix regression technique (MCPMRT), matrix regression approach (MRA), Random Forest Analysis (RFA), Structural equation modelling (SEM), and Linear Model with Permutation (LMP).

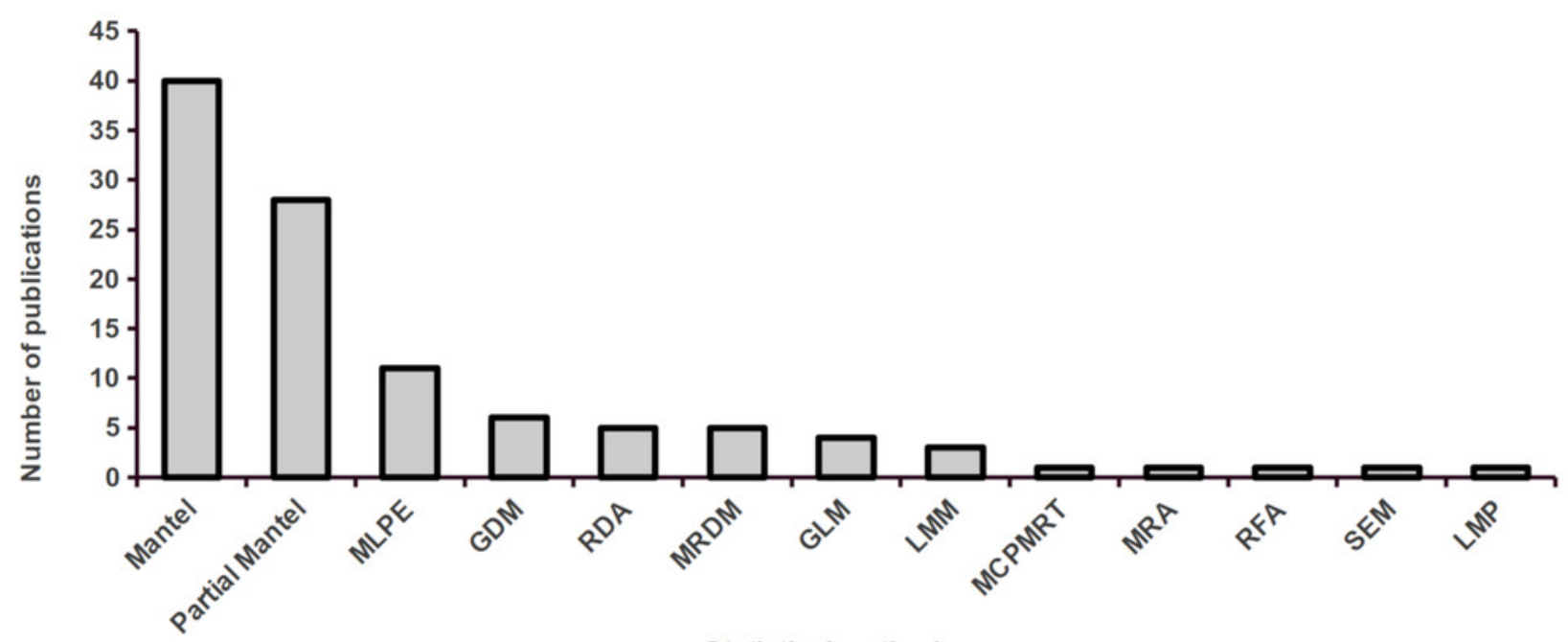

Statistical method 
Figure 6

Number of studies focusing on different landscape effects on gene flow for each taxonomic group.

See Dataset S1 for details on the reported effects.

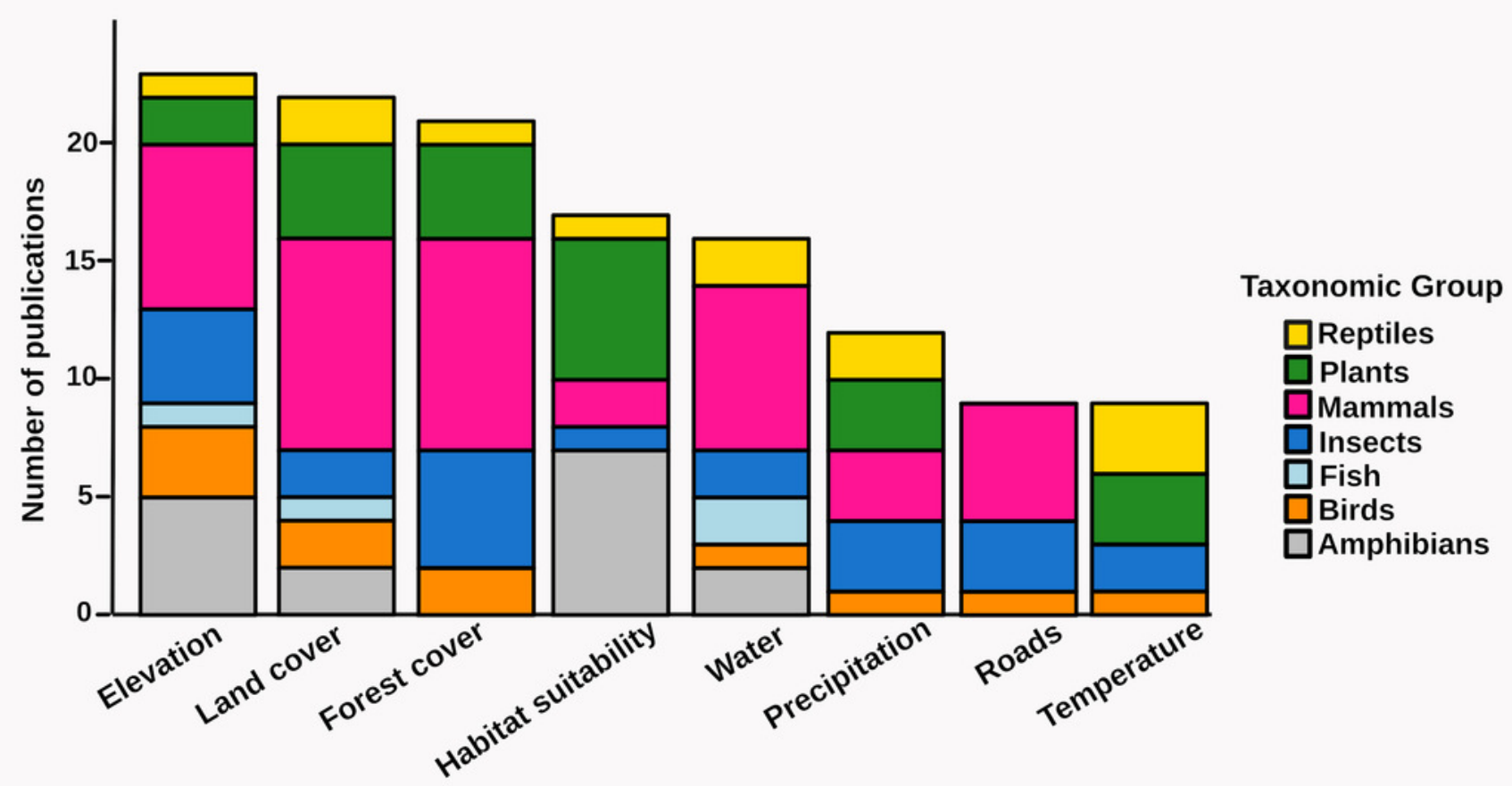


Figure 7

Individual-level effect sizes for isolation by geographic distance (a), isolation by elevation (b) and isolation by forest cover (c).

Dots represent effect sizes and colors indicate taxonomic groups. Significance of the effects reported in the original articles is also highlighted.

(a)

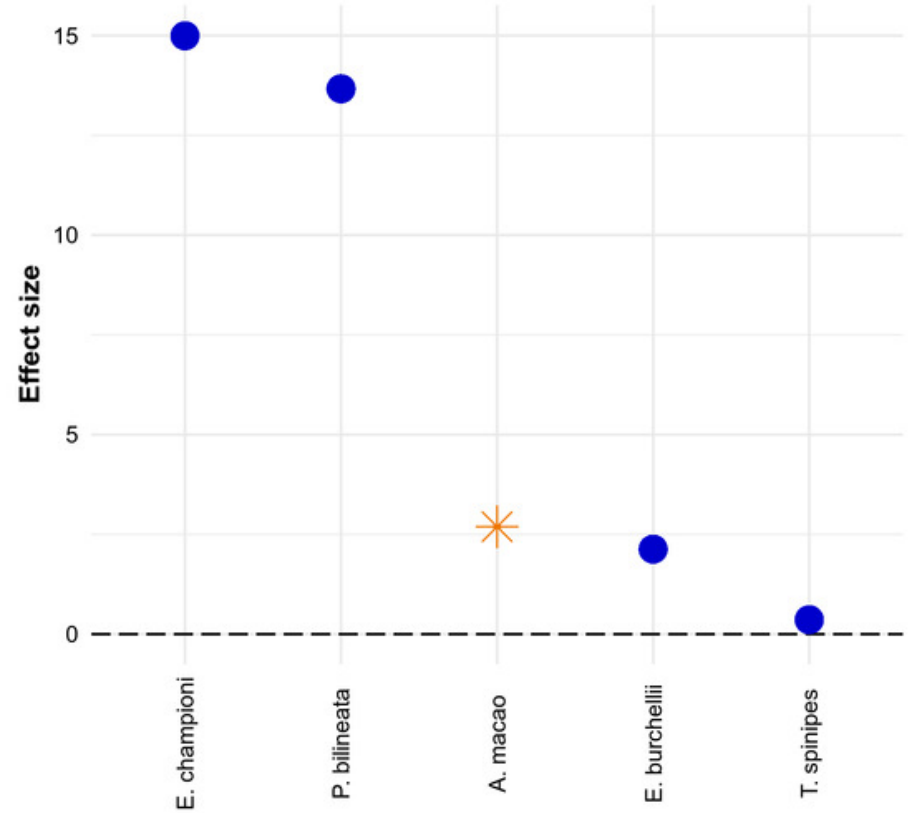

(c)

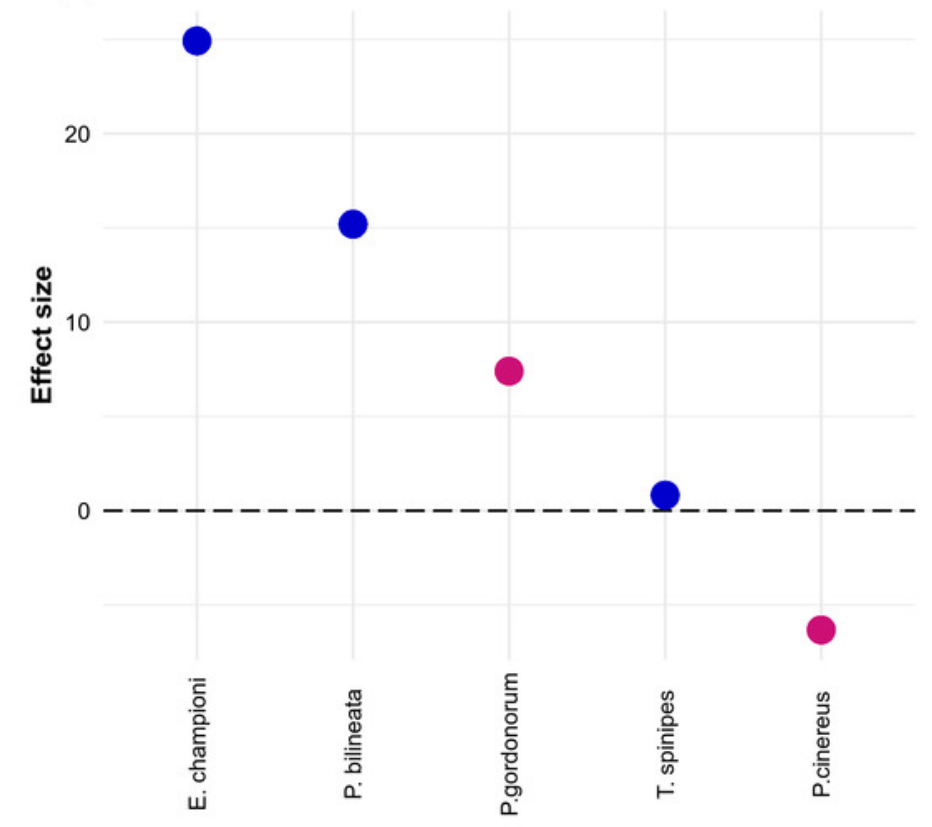

(b) Elevation
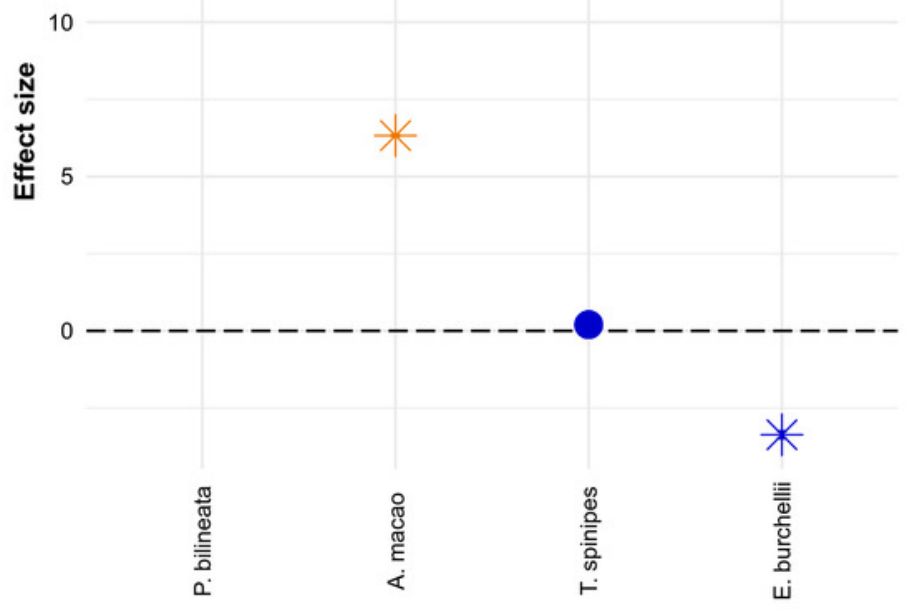

Taxonomic Group

Bird

Insect

Mammal

\section{Significance}

$p>0.05$

* $p<0.05$ 
Figure 8

Population-level effect sizes for isolation by geographic distance (a), elevation (b), precipitation (c), temperature (d) and forest cover (e).

Dots represent effect sizes and colors indicate taxonomic groups. Significance of the effects reported in the original articles is also highlighted.

(a) Geographic Distance

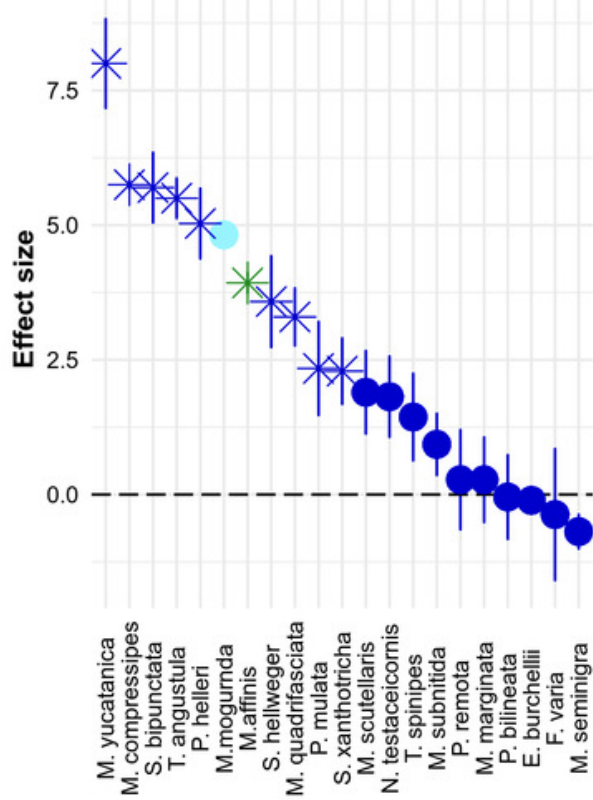

(d)
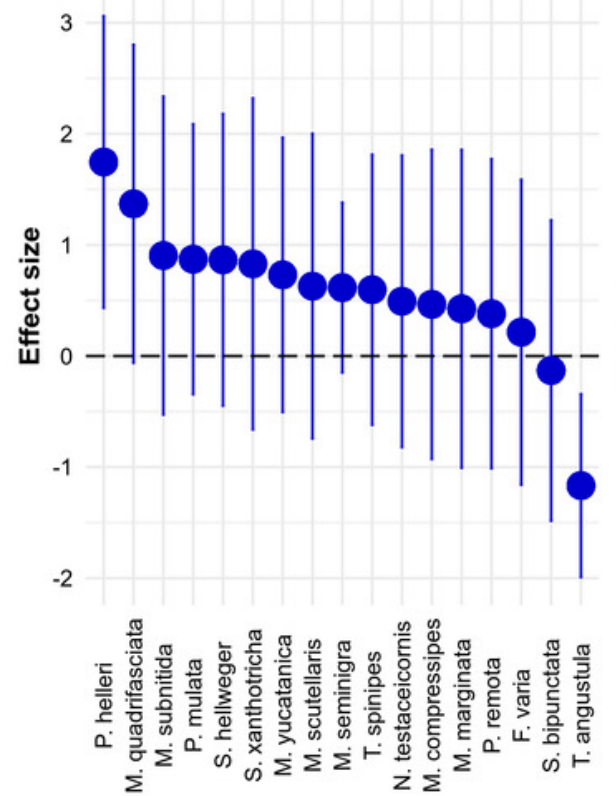

(b)
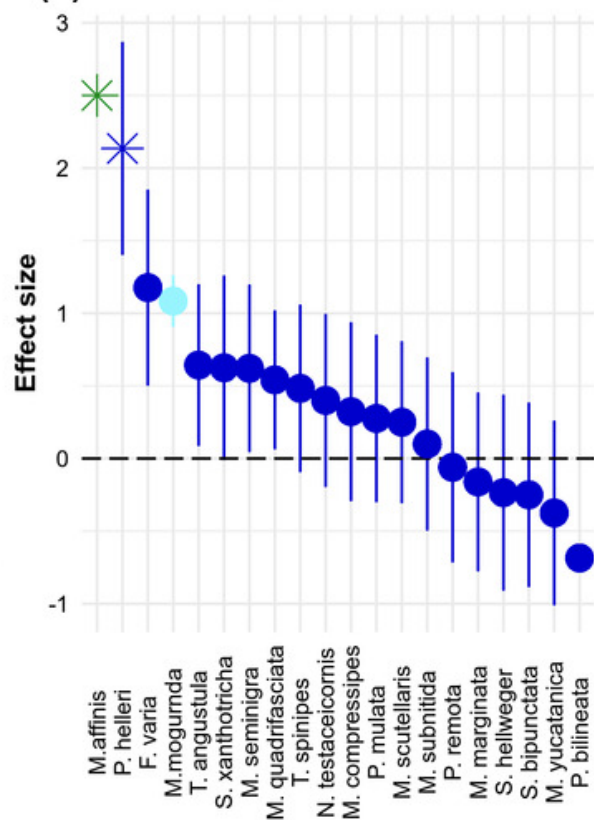

(e)

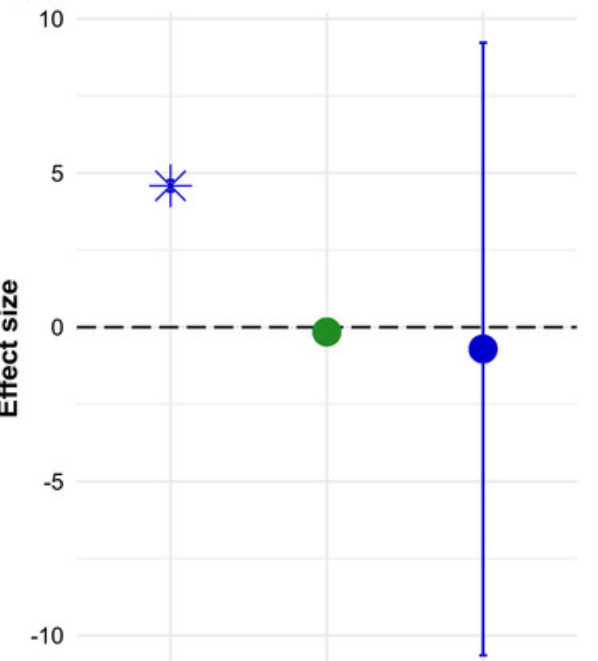

(c) Precipitation
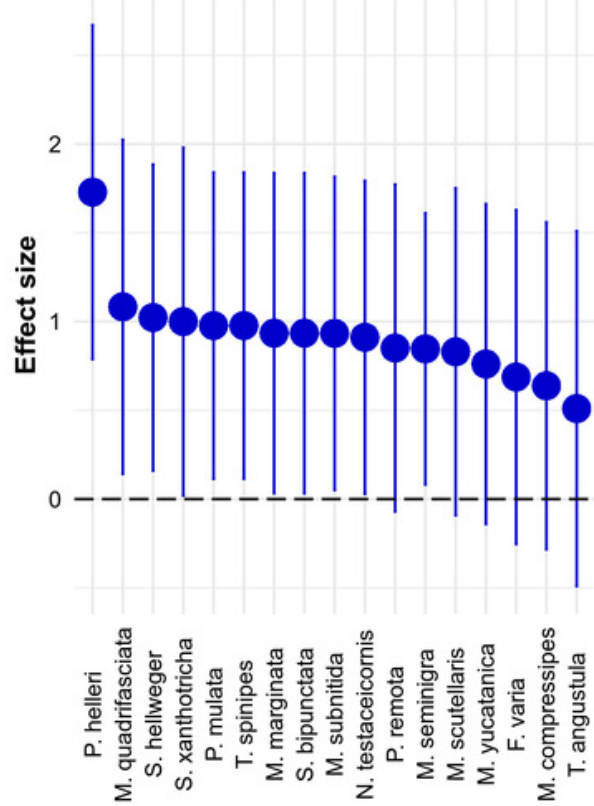

Taxonomic Group

Fish

Insect

Plant

Significance

P $p>0.05$

* $\mathrm{p}<0.05$ 